\title{
Website Effectiveness in Wellness Promotion By Portuguese Spas
}

\section{Veronika Joukes and Chris Gerry}

Universidade de Trás-os-Montes e Alto Douro, Portugal

\begin{abstract}
Until 2004, Portuguese spas were traditionally thought of as establishments in which noninvasive therapies based on naturally occurring sources of mineral water are provided under professional supervision. With the publication of the Decree-Law No. 142/2004, Portuguese legislation regulating spas changed quite dramatically: from that moment on, spa-owners, numbering some 40 establishments countrywide, were allowed to open up what had hitherto been a strictly health-orientated sector. Since then much has changed in the Portuguese mineral springs spa market: one of the main innovations has been the introduction of a large variety of services that may be termed 'wellness treatments' - therapies not strictly related to pre-existing health conditions. These are now being offered as a product range in their own right, along with traditional medical treatments, thus diversifying the services provided, with all based on the same highly therapeutic naturally occurring mineral water. Thus spa services are no longer just a health product but have also become a tourist attraction, thereby legally formalising something that, to a limited extent, had always been the case. With the change in the services offered, the typical customer profile has also modified significantly: users of today's spa facilities are younger (between 25 and 45 years of age) than in the past, from the middle- to middle-upper socioeconomic stratum, live in large urban centres, have a reasonably high level of education, and could be either male or female. Such clients often prefer making various short trips over the year to test out different destinations, and choose registered hotels with three or more stars for their stays. The changing client profile has forced firms to adapt the means they employ to establish a growing and loyal client base. Indeed, over the past five years, a large majority of Portuguese spa service providers have significantly upgraded not only their services and infrastructures, but also their use of internet sites. With these changes in mind, the study reported on here aimed to analyse the way such firms currently communicate with prospective clients using the web. The results of this study may offer both Portuguese spas and those in other locations the opportunity to further improve their dialogue with current and potential spa-goers.
\end{abstract}

Keywords: mineral springs spas, website effectiveness, internet promotion, health and wellness tourism, Portugal
In Portugal, the supply side of health and wellness tourism consists of traditional spas based on natural mineral water springs that have existed since Roman times at least, some thalassotherapeutic establishments (registered from 1990, and using therapies exclusively based on sea water), as well as a fast-growing number of nonmineral water spas (established since the beginning of the 21 st century, based on water from the public supply network). In numerical terms this situation translates into the following structure of suppliers: 38 mineral springs

\section{Correspondence}

Professor Veronika Joukes, Department of Economics, Sociology \& Management (DESG) and Centre for Transdisciplinary Development Studies (CETRAD), Universidade de Trás-os-Montes e Alto Douro (UTAD), Avenida Almeida Lucena 1, 5000-660 Vila Real, Portugal. E-mail: veronika@utad.pt spas that, in $2008,{ }^{1}$ were open to the public (Turismo de Portugal, 2009b); fewer than 10 seawater units functioning in 2010 (Fernandes, 2006; Turismo de Portugal, 2009a); and approximately 130 hotels with spa facilities reported by the Portuguese Hotel Association (AHP) for the same year, which corresponds to an increase of more than $1500 \%$ over the last eight years in the number of functioning 'spa hotels' (Turismo de Portugal, 2010a). Meditative and holistic retreats and medical tourism the latter focusing particularly on aesthetic/cosmetic, dental and surgical treatments - are both still in the introductory stage of their life cycle. Consequently it is impossible to quantify their current share of the market - either because they are not yet the object of intensive promotion efforts and/or because these subsectors' activities still remain largely unstructured.

This article focuses on the spas that are based on mineral springs, commonly referred to in Portuguese as 
termas (the local adaptation of the Latin thermae, meaning hot springs/baths). In order to avoid misunderstandings and to emphasise the unique Portuguese context, it should be highlighted that for the Portuguese consumer the concept of 'going to the termas' has long meant undergoing therapy based on mineral water springs for a pre-existing condition - only those who were ill would 'take the waters' and, consequently, mineral springs spa facilities were sought only by the unhealthy and the elderly. However, the number of spas nowadays greatly exceeds the number of termas, and recent intensive marketing and awareness campaigns have facilitated the introduction of the spa concept in Portugal, where the latter is now understood as a place (in an urban/rural environment, in a hotel/fitness complex, in a beauty centre or even in the traditional termas) where one can be pampered, not because one is ill, and not necessarily with (mineral) water treatments. Another difference must be stressed, important for the development of tourist products, between spa hotels and termas: the latter normally do not offer accommodation. Yet the traditional termas are no longer seen as mere therapeutic infrastructures but also, and increasingly so, as places of leisure, recreation and relaxation. While in principal the two dimensions of therapy and recreation are two facets of contemporary spas that can coexist in perfect harmony, the services provided by the emerging wellness tourism market in Portugal are still thought of as being quite separate from those offered by the turismo termal market (spa-based medical tourism), as Portugal has a much longer tradition in the latter field (Lapa, 2009).

The main reasons for finding these spas of analytical interest is that they (a) are owned by relatively small public entities or by private investment groups, (b) are typically autonomous rather than part of a major grouping or conglomerate and (c) are experiencing a phase of significant adaptation that obliges them to market their services more directly and aggressively.

Based on a previously conducted literature review, the empirical research analysed half of the total number of existing spa websites in order to find out to what extent and in what manner Portuguese spas now use internet marketing and website design to promote their new services. However, before presenting the results of the content analysis applied to the data collected, the general context in which these mineral springs spas have evolved and today's typical spa-goer will be described.

\section{The Main Characteristics of Portuguese Mineral Springs Potential}

In Portugal, 408 springs with mineral water are reported to have therapeutic properties, and three-quarters of them (300) are recognised by the local population as having curative properties (Sousa, 2006). In the spring of 2010, while 44 such spas were officially being exploited, only 39 were open to the public, two more than in the previous year. The central region of Portugal has 20 spas (or $45 \%$ of the total), the north has 18 (41\%), while only $14 \%$ of the total number of termas are located in the remaining four regions - three in the Alentejo and one each in Lisbon, the Algarve and the Azores, as shown in Figure 1 (Associação das Termas de Portugal [Portuguese Spa Association] ATP, 2010; Turismo de Portugal, 2009b).

The largest Portuguese termas are to be found in the central region, more specifically around São Pedro do Sul, attracting 17,017 medical spa-goers in 2008. The second largest facility with regard to this kind of public is located in the north: however, Termas de Chaves, a municipal company, handled only a little more than one-third $(6,374)$ of the medical spa-goers that its direct competitor Termas de São Pedro do Sul achieved over the same period. This considerable discrepancy goes some way to explaining why the north only received 25,814 mineral springs spa-goers in 2008, while the centre attracted more than double that figure (58,870; Turismo de Portugal, 2009b).

The data presented in Table 1 show that exactly half of the units are publicly owned and the other half are in private hands. Contrary to what we might expect, $62 \%$ of the 21 renovation projects so far executed were initiated by publicly owned companies. Of the five such projects still to reach their final stage, however, four are private. Of the 18 establishments where apparently no improvements have been undertaken, $44 \%$ are publicly owned.

It is also important to note that of the 44 units under consideration (41 ATP members and three independent ones), $21(48 \%)$ have already renovated their premises since 2000 and another five $(11 \%)$ are to reopen within a short span of time.

We also found that it is the smaller units that face the greatest difficulties in achieving the renovation that would contribute to their adapting to the new market conditions. Of the 15 termas that had less than 1,000 medical clients in 2008 , seven remain in exactly the same physical state as in 2000 , two are under reconstruction and six have already concluded their renovation work. In contrast, the 10 termas with the best sales figures had all concluded such projects by 2010 .

The figures cited above illustrate that Portuguese mineral springs spa owners seem to be following the global wellness trend, or as Erfurt-Cooper and Cooper put it: 'Wellness facilities and programmes became a worldwide tourist attraction during the last decade of the 20th century and this trend shows no sign of abating, with excellent prospects for continued growth in the future' (Erfurt-Cooper \& Cooper, 2010, p. 1).

\section{Table 1}

Renovation of Publicly- and Private-Owned Termas (2010)

\begin{tabular}{lccc}
\hline & $\begin{array}{c}\text { Publicly-owned } \\
\text { termas }\end{array}$ & $\begin{array}{c}\text { Private } \\
\text { termas }\end{array}$ & Total \\
\hline Renovation projects (concluded) & 13 & 8 & 21 \\
Renovation projects (in progress) & 1 & 4 & 5 \\
Without renovation projects & 8 & 10 & 18 \\
Total & 22 & 22 & 44 \\
\hline Source: & $\begin{array}{l}\text { Authors' estimates based on the termas' websites (see list and respective addresses in } \\
\text { Table 2) and on the following publications ATP, 2010; Medeiros \& Cavaco, 2008; Turismo de } \\
\text { Portugal, 2009b. }\end{array}$
\end{tabular}




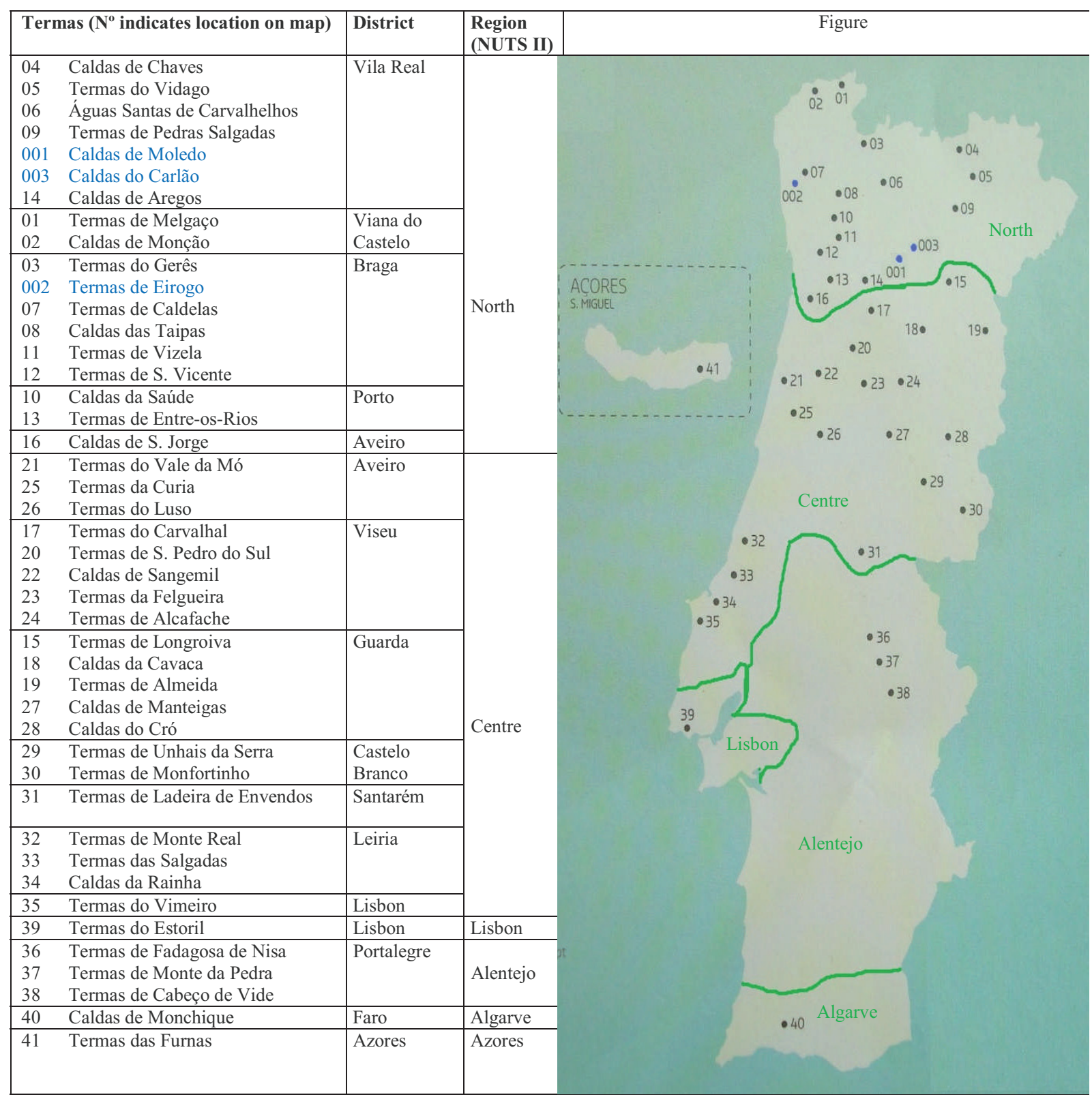

\section{Figure 1}

Spatial distribution of Portuguese mineral springs spas by NUTS II (2010).

Key: 3 independent spas (Moledo, Eirogo and Carlão) are indicated in blue, all the others being ATP (Associação das Termas de Portugal) members; the limits of the NUTS II subregions are indicated in green.

Source: Mapped by the authors based on ATP (2010), INETI (2004) and Turismo de Portugal (2009b).

Note: NUTS is the abbreviation of Nomenclature of Territorial Units for Statistics, a hierarchical system for dividing up the economic territory of the EU for the purpose of statistics, socio-economic analyses and the framing of regional policies. There are 3 levels; NUTS 2 being the intermediate level that delimits basic regions for the application of regional policies.

\section{Today's Typical Spa-Goer}

In his doctoral research, Gustavo (2009) examined clients' motivations, the kind of services they prefer during a spa stay in Portugal and their daily healthcare practices at home. In order to concentrate on this growing new segment of spa-goers, he disregarded 'traditional' spa clients - the elderly persons with pre-existing medical conditions requiring curative treatments, characterised also by limited purchasing power and by low expectations as to the quality of spa facilities and of the accommodation typically offered only during the warmer months of the year
(Medeiros \& Cavaco, 2008). The answers Gustavo collected from 824 respondents interviewed from May to August 2009 in 21 'classic' and 'new' hydro-therapeutic leisure units, led him to conclude that the typical spa-goer today is predominantly female $(70 \%)$, in their late thirties, with a higher education degree (74\%), evenly divided between single persons and those in a stable conjugal relation ( $25 \%$ and $24 \%$ respectively), many without children, and living in an urban area $(72 \%)$ typically in Portugal $(73 \%)$. The vast majority (92\%) are in employment, predominantly in higher level managerial or technical posi- 
tions, $89 \%$ of which in the service sector. In almost half of the cases, the family net income exceeds $3,000 €$ per month (i.e., more than six times the 2009 Portuguese guaranteed minimum income of $450 € /$ month).

Those interviewed by Gustavo visited spas regularly (31\% of them monthly) in order to relieve stress or to relax $(74 \%)$ and/or to upgrade their mental and physical health $(50 \%)$. Massage and body treatments were the spa services with most demand. Notwithstanding the dominant historical and cultural influence of the classical termas, nearly $50 \%$ of the clients said they had not undergone hydro-therapeutic treatments during their last spa visit. The same questionnaire also revealed that spa clients are essentially healthy people: $87 \%$ of those surveyed consider their routines as healthy, stressing the importance of food $(89 \%)$ and physical exercise $(83 \%)$ and their personal attitude in favour of a healthy lifestyle tout court (54\%).

Gustavo's findings demonstrate that the profile of today's Portuguese spa-goers fits perfectly into the changing 'global spa-goer landscape' (Azman \& Chan, 2010; Koh, Yoo, \& Boger, 2010; Konu \& Laukkanen, 2010; Lehto, Brown, Chen, \& Morrison, 2006; Smith \& Laszlo, 2008).

\section{Principal Results of the Analysis of 15 Mineral Springs Spa Websites}

The internet is attractive both to those on the demand side (seeking information) and those on the supply side (seeking to disseminate information) and constitutes the only medium capable of furnishing round-the-clock, 'instant' and up-to-date information on new techniques, products and services. In the sector under analysis here, as elsewhere, the internet makes it easy for service providers to innovate, reinvent and promote service packages and incentivise termas to continuously develop their communicative capacities and to explore the marketing techniques to the limit in the context of a market niche of substantial commercial interest (Buhalis, 2003; Gustavo,
2009; Hallem, Barth, \& Triki, 2010; Milheiro, 2006, pp. 100-105).

Though a substantial amount of tourism website evaluation has been conducted worldwide over the last two decades (Law, Qi, \& Buhalis, 2010), so far no research has been undertaken in Portugal into the internet marketing strategies of spas, neither have their websites been analysed in any systematic way. In an attempt to fill this gap, the existing companies' websites were systematically screened during the spring of 2009 (30 sites) and 2010 (34 sites), with a view to finding answers to the following questions: ${ }^{2}$.

1. How do they position their medical/wellness products?

2. To what kind of public do they address their internet-based marketing efforts?

3. Do they only mention their own services or do they also provide prospective clients with links that give information on other service providers, such as travel experts, sports organisations or nature guides?

4. Do the online marketing tools used by these spas stimulate user-communities?

The study reported on here concentrated on the years 2009 and 2010: in 2009, 37 termas were open to the public, of which 30 had a website, while in 2010 two more termas were functioning (bringing the total to 39), of which 34 promoted their services through the internet. In the two years under consideration, the arguments advanced by firms for not employing a website were: (1) that it was currently renovating their facilities and that there would be few if any returns deriving from an internet site; or (2) that the firm's main clients were principally local elderly customers, the spa facilities were limited and only open during a short period of the year and that therefore there was little hope of attracting new segments of spa-goers. As a matter of fact, in three (Almeida, Monte

\section{Table 2}

Spa Websites Analysed

\begin{tabular}{|c|c|c|c|c|c|c|c|}
\hline Name & $\begin{array}{c}\text { Region } \\
\text { (NUTS II } \\
\text { level) }\end{array}$ & $\begin{array}{c}\text { Ranking no. } \\
\text { of medical } \\
\text { spa-goers }\end{array}$ & $\begin{array}{l}\text { No. of medical } \\
\text { spa-goers } \\
(2008)\end{array}$ & $\begin{array}{c}\text { Renovated } \\
\text { during } \\
\text { last decade? }\end{array}$ & $\begin{array}{l}\text { Concession- } \\
\text { holder in } 2010\end{array}$ & $\begin{array}{l}\text { Accommodation } \\
\text { provided? }\end{array}$ & Website address \\
\hline São Pedro do Sul & Centre & 1 & 17,017 & 2005 (Sept)-2007 (June) & Municipality & No & www.termas-spsul.com \\
\hline Chaves & North & 2 & 6,374 & 2005 (May) & Municipality & No & www.termasdechaves.com \\
\hline Felgueira & Centre & 4 & 4,511 & No (1997) & Private & Hotel & www.termasdafelgueira.pt \\
\hline São Jorge & North & 6 & 3,655 & 2003 & Municipality & No & www.termas-sjorge.com \\
\hline Gerês & North & 8 & 3,443 & 2007 (Jan) & Private & No & www.aguasdogeres.pt \\
\hline Monfortinho & Centre & 10 & 2,358 & 2000 (Aug) & Private & Hotel & www.monfortur.pt \\
\hline Saúde & North & 15 & 1,326 & No (1994) & Private & No & www.caldas-da-saude.pt \\
\hline São. Vicente & North & 16 & 1,258 & 2008 (June) & Private & hotel & www.termas-svicente.pt \\
\hline Luso & Centre & 18 & 1,176 & 2010 & Private & Hotel & www.termasdoluso.com \\
\hline Longroiva & Centre & 21 & 1,004 & 2009 (Oct) & Municipality & No & www.termasdelongroiva.com.pt \\
\hline Vimeiro & Centre & 22 & 637 & No & Private & hotel & www.termasvimeiro.com \\
\hline Monchique & Algarve & 23 & 621 & 2002 (May) & Private & Hotel & www.monchiquetermas.com \\
\hline Aregos & North & 24 & 604 & 2009 & Municipality & No & www.termas-caldasdearegos.com \\
\hline Cavaca & Centre & 28 & 421 & 2008 (July) & Municipality & No & www.caldasdacavaca.pt \\
\hline Furnas & Azores & No data & No data & 2008 (Oct) & Private & Hotel & www.furnasspahotel.com \\
\hline
\end{tabular}


Real and Nisa) of the four cases of new websites created in 2010, the website launch coincided with the reopening of the premises after renovation, while the creation of the Taipas website has to be interpreted as part of the 20102013 plan of its newly elected board that, among other objectives, intends to redefine its public and modernize the spa (Taipas Turitermas, 2010).

In the same period, nine termas merely offered basic information posted on the website of an 'umbrella' institution. With the exception of Cabeço da Vide, the termas with over 2,000 medical spa-goers per year (corresponding to $1 / 3$ of the termas with a website link) have their own appealing websites, whereas of the 15 smaller spas (receiving less than 1,000 visitors in 2008), four have no website at all and four only furnish the most basic details through an 'umbrella' website. The internet presence of termas open to the public and with accommodation is $100 \%$ and $85 \%$ of those without integrated accommodation.

We conclude that the internet presence of Portuguese spas is high, certainly when spa hotels and larger companies are taken under consideration.

In order to find out how the termas use the internet to sell their services, it was decided to focus on those that had created their own web site (excluding those with information inserted on an 'umbrella' site) and that had been functioning in 2009 and 2010. This group of spa units (1) was representative of the regional distribution of spas, (2) included both private and public initiatives, (3) took in both well-visited and less-visited businesses and (4) incorporated both spa hotels and those spas that provide no accommodation (balneários). As there were only two eligible sites in the south of Portugal, the sample taken from this group was adjusted to include seven sites in the centre of the country and six in the north, respecting the $14 \%-45 \%-41 \%$ spatial distribution ratio referred to above, as can be verified in Table 2 .

As mentioned above, modernisation efforts on the part of the owners of mineral springs spas did not stop at infrastructural renovation projects: many also established internet sites, on which they placed and managed different types of information. Some of the more interesting aspects of the internet sites encountered in our analysis are presented below and are the result of a content analysis conducted on 15 carefully selected web sites. Due both to the particularity of the sample, the type of research questions posed and the pilot nature of the study, no pre-existing content analysis methodology was used. The research questions - on positioning/promotion, target public, clusters/networks and interactivity - provided the basis for the creation of four clusters of variables (properties and features) that were systematically examined on each website, thus favouring the type of counting method proposed by Law et al. (2010).

The following paragraphs summarise the Portuguese 'state of the art' in regard to the following topics: (1) positioning and promotion of the products (therapeutic versus wellness; basic versus rich information); (2) target public (traditional/new spa-goer; niche/age/gender specific; disabled people, and so on); (3) clusters/networks of firms (within or outside the sector); (4) interactivity (hyperlinks, online enquiry form, discussion forum, multimedia, online transactions).

\section{Positioning and Promotion}

Of the sites that offer only classic treatments, all but two use different subpages to recommend both medical and wellness products. However, the degree of detail in the information provided is variable. In the majority of cases, sites not only summarise the treatments available, but also explain them: three do so with photos, and the São Jorge site supplies a glossary of almost 30 terms. Only a few bring together frequently asked questions in a dedicated 'FAQ' subpage. All units, apart from Furnas, present a detailed price list; however, it is only on rare occasions that potential clients are informed of the time required for each treatment. Almost all termas differentiate their prices following one or more of the following criteria: (1) the longer the stay and/or the more treatments acquired, the lower the unit price; (2) prices vary according to (low, middle or high) season; (3) returning customers receive discounts; (4) group bookings pay less; and (5) in spa hotels, prices change according to whether the treatment is bought with or without accommodation.

None of the termas created a subpage with general tips on healthy lifestyle, although some do mention that they have a staff nutritionist and it is in this context that certain advice is given. None of the termas published a code of ethics, but São Jorge does mention a small list of commitments regarding the quality of the services offered. None of the termas explicitly mentions its concern for the principles of sustainability and local development. Implicitly, some display pronature values, describing the spa's healthy surroundings in their introductory texts or including 'green' pictures on the opening page of the site or in the site's photo gallery. Only on the São Pedro do Sul site is there a subpage entitled 'quality and environment' that includes a manual of environmental good practices (boas práticas ambientais).

All termas provide correct basic information about their services. However, most miss the opportunity to profile themselves in a positive way, for example, guaranteeing access to supplementary details that differentiate their services from competitors and sharing their concern about, for example, the local environment and sustainable development.

\section{Targeting the Public}

The way termas address their public is still very general. However, there are exceptions to the rule. In a more or less obvious way, the São Jorge, São Pedro do Sul, Felgueira and Monchique units inform clients that they welcome children: Monchique has a Kids' Club, and Felgueira provides the younger generation with a junior passport and has created the mascot Felgui, following the example of Afonsinho the frog and Amelinha the squirrel launched by the São Pedro do Sul termas to appeal to clients' children. Monfortinho, to some degree, focuses on clients visiting the area for the purpose of hunting, while Monchique does something similar to attract the sailing community and Vimeiro targets equestrians and golfers. 
Águas do Gerês hopes to conquer nature tourists, mentioning its unique localisation in the Peneda-Gerês National Park.

The languages used on the site indicate that the domestic market is at the primary focus, since all sites open in Portuguese and only a few guarantee the option to read (in part) the content in Spanish, French and/or English.

Only the Caldas de Aregos site has the Web Access Symbol for people with disabilities (a blue globe, marked with a grid, tilted at an angle with a yellow keyhole in the middle) at the bottom of its main page. ${ }^{3}$

Two-thirds of the websites consulted try to retain the loyalty of their clients by offering them the possibility of subscribing to their newsletter. It should be noted that, in most cases, prospective clients will not receive a real newsletter, but rather will be notified of all the promotions and initiatives of the enterprise. Eight websites used the main page of their website as an alternative way of announcing these kinds of special promotional campaigns.

In a market where prior knowledge of the customer is so important and e-marketing increasingly personalised, spas seem to be lagging behind. Obtaining precise customer profiles might help them to elaborate more efficient strategies; precisely for this reason, greater adherence on the part of spa managers to the Spa E Thalasso Monitor, launched by the Portuguese Hotel Association (AHP) in May 2009, would seem appropriate. All participating hotel units in the sector are provided with free access to this benchmarking system that produces operational management information relevant for this market. 'The Monitor' is supported by software that allows, at any time, all member businesses to review their (historical) data and compare the position of their own unit relative to others in the same or in different regions of Portugal. It fills a serious gap in technical information available on this segment, making accessible monthly updated operational indicators as well as data on market activity, providing a business management tool; furthermore, public tourism officials (local, regional and national) are guaranteed access to reliable information on their geographical area whenever needed (AHP, 2009; Mourão, 2010).

Portuguese spa managers may also find the annual forecasts from SpaFinder helpful in defining their marketing strategies: compiled by 'a team of experts who visit thousands of spas', these reports are based on interviews with top industry analysts and research organisations, and review ongoing consumer and industry research in the spa, travel, wellness and beauty sectors. In December 2009, SpaFinder launched its Top 10 Global Spa Trends to Watch in 2010, identifying global spa trends that will influence spa experiences for both consumers and the industry in 2010 and for years to come. The report argues that 'prevention is the new P-word' (substituting its predecessor - 'pampering') and claim that belonging to a spa, rather than just visiting it, increases one's emotional health. They defend that, while the spa industry's virtual presence will continue to grow, room has to be made for 'wellness tourism'; and they also foresee an era of integrated spa, fitness, health, spiritual, wellness and beauty facilities (SpaFinder, 2010).

\section{Clusters/Networks}

São Pedro do Sul is the only one of the termas that can afford the luxury of investing in a year-round program of events and activities for its guests. The monthly program can be downloaded from the internet. Smaller units like Chaves, São Jorge and Monchique only produce this kind of program in the high season. In most cases, future clients are not informed or are only informed in a very brief and vague way about complementary tourist activities in the surrounding area. São Pedro do Sul and Chaves, owned by the municipality, limit themselves to inserting links to other organisations that are patronised (and to some degree legitimised) by the municipality. No more than a handful of links was oriented towards providing information regarding 'independent' companies that offered specialised tourist activities (e.g., river trips, local wildlife), or concerning the local zoo, museum or geopark. Monfortinho is an exception inasmuch as it mentions other spas, some of which are direct competitors, be it Vimeiro (which belongs to the same group) and the Portuguese Spa Association (which can also be accessed via the website of São Pedro do Sul). All the spas that are integrated into hotels refer to their own accommodation, while six balneários mention the addresses of local lodgings, and two also list nearby restaurants.

As most people also have time for activities other than spa-based health and wellness treatments, spas can offer their own complementary activity program. If they prefer not to do so, it is in their own interests to offer website links to competitors within the sector or to tourism/leisure companies in the vicinity, as the value of networking in tourism is now widely recognised (Lazzeretti \& Petrillo, 2006; Swarbrooke, Smith, \& Onderwater, 2004).

\section{Interactivity}

All the termas are reachable across the internet by a click on their e-mail address. One third offer the possibility of filling out an online 'message' form. More than half offer online reservation possibilities, although in three cases this is limited to hotel reservation. São Jorge and Felgueira give their clients the additional facility of telephoning them free of charge.

With regard to other aspects of online interactivity, scores are still very low: no unit has set up a discussion forum; only one has a website poll question, with questions such as: 'Are you aware that a spa cure can benefit from refunds from the national health service?' Five spas give customers' opinions, albeit in a partly 'censored' form. Exceptionally, there is a link to social network pages as Twitter and Facebook and only one unit has a blog.

Merchandised products are available on two sites and, in one case, can be individually ordered online and paid for in the traditional way (by cheque, ATM code number or bank transfer); in the latter case an online shopping option (with a cart) is to be established, but was not yet operational at the time of research. Recalling Gustavo's (2009) findings that $14 \%$ of those answering the questionnaire were in the spa at the time as a result of having received a gift voucher, it is interesting to know that only three units offer such vouchers. 
As almost half of the population in Portugal has access to the internet (Miniwatts Marketing Group, 2010), including the new spa-goer (Gustavo, 2010), more advantage should be taken of multimedia and highly interactive web opportunities.

\section{Conclusions}

Having noted that the large majority of the providers of mineral springs spa services have been significantly upgrading not only their infrastructures and services, but also their websites over the past five years, the authors analysed the way spas currently communicate with their clients (existing and prospective) through the internet. We concluded that the Decree-Law No. 142/2004 has brought about real changes: the majority of Portuguese mineral springs spas now offer medical along with wellness services and inform prospective clients correctly and honestly about what to expect. Nevertheless, here are still numerous opportunities for spas to improve their internet presence in many directions: by putting more (and more accurate) information on their sites, they will be able to target special groups and market segments, redirecting prospective clients to complementary tourist activities and expressing their concern over environmental, sustainability and local development issues. Termas would be well advised to develop their interactivity by creating discussion forums, making their sites more accessible, offering more online shopping possibilities, taking more advantage of social networks and creating more transparent subpages in which clients can express their opinions. Our sample, moreover, provides evidence that the more content and links are put on the internet, the better informed clients will become and the more likely it will be that existing and potential clients will feel attracted by the products and services offered. We are also convinced that even the smallest spa units can benefit from developing focused and functional websites.

This preliminary study was undertaken on our own initiative in order to help the local termas to make their websites more effective with a view to retaining existing and attracting new clients. It is, however, our intention to convert this first effort into an international comparative project capable of furnishing results more widely applicable to the sector under consideration. In our opinion the results of this study offer not only Portuguese mineral springs spas but spas in general the chance to further improve their internet dialogue with current and potential spa-goers. In fact, now that the use of the internet in the health and wellness value chain seems to be increasing significantly (Pesonen \& Palo-oja, 2010), the importance of using a global and globally accessible medium more efficiently and interactively to consolidate the presence of all the sector's service providers (including those in complementary activities) is undeniable.

It is to be hoped that this pilot research will help to encourage researchers in this field to develop a more comprehensive international and comparative study of spa websites based, for example, on an adapted version of the Extended Model of Internet Commerce Adoption (eMICA; Burgess \& Cooper, 2000; Pesonen \& Palo-oja,
$2010),{ }^{4}$ so that guidelines for best practices to promote improved website effectiveness may be developed.

\section{Endnotes}

1 The most recent official statistics referring to the sector date from 2008.

2 The authors would like to express their thanks to the first-year students of UTAD's Tourism degree (Ana Carina Lima, Ângela Silva, Carla Machado, Cátia Rodrigues, Marta Mota, Natércia Lourenço, Rita Teixeira, Sara Rebelo, Sara Teixeira, Sónia Ala, Telma Castilho, Telma Guerra, Teresa Gonçalves and Tiago Araújo) who, during February 2009 , helped to collect some of the data necessary for this article.

3 There is no guarantee that a site using this symbol will be $100 \%$ accessible, or was even designed according to the guidelines: website users 'do so at their own discretion' and it is their responsibility to 'let the webmasters know when a site is or is not accessible to the disabled, and to offer suggestions for greater accessibility' (Web Access Symbol, NCAM, n.d.).

4 In his comments on a draft version of this article at the annual conference of the European Chapter of the Travel and Tourism Research Association, devoted to the theme of 'Health, wellness and tourism: Healthy tourists, healthy business?', organised in Budapest from September 1 to 3, 2009, Juho Pesonen suggested using the eMICA model in order to present internationally comparable results. For this useful suggestion he deserves our thanks.

\section{References}

Associação da Hotelaria de Portugal (Portuguese Hotel Association). (2009). Como aderir ao Spa E Thalasso Monitor. Retrieved February 3, 2010, from http://www.hoteis-portugal.pt/?data=read. obj\&mod $=$ news\&aid $=1500$

Associação das Termas de Portugal (Portuguese Spa Association). (2010). Turismo de saúde e bem-estar. Health and wellness tourism. Lisbon: Author.

Azman, I., \& Chan, J.K.L. (2010). Health and spa tourism business: Tourists' profiles and motivational factors. In L. Puczkó (Ed.), Health, wellness and tourism: Healthy tourists, healthy business? Proceedings of the Travel and Tourism Research Association Europe 2010. Annual Conference. 1-3 September, Budapest, Hungary (pp. 9-25). Dalarna, Sweden: Travel and Tourism Research Association Europe.

Buhalis, D. (2003). eTourism: Information technology for strategic tourism management. Harlow, UK: Financial Times Prentice Hall (Pearson).

Burgess, L., \& Cooper, J. (2000, November). Extending the viability of MICA (Model of Internet Commerce Adoption) as a metric for explaining the process of business adoption of Internet commerce. Paper presented at the International Conference on Telecommunication and Electronic Commerce. Dallas, TX.

Decreto-lei no. 142/2004, de 11 de Junho. (2004). Diário da República, Portugal, pp. 3632-3641.

Erfurt-Cooper, P., \& Cooper, M. (2010). Health and wellness tourism. Spas and hot springs. Bristol, Buffalo and Toronto: Channel View Publications.

Fernandes, J.V. (2006). Thalassa, thermae, SPA-Salute per qqua. Lisbon: Plátano Editora.

Gustavo, N. (2009). Turismo de saúde. Uma abordagem à luz dos desígnios do século XXI. In J.M. Simões \& C.C. Ferreira (Eds.), Turismos de nicho. Motivações, produtos, territórios (pp. 191-204). Lisbon: CEG.

Gustavo, N. (2010). Health tourism: The SPA goers in Portugal. In L. Puczkó (Ed.), Health, wellness and tourism: Healthy tourists, healthy business? Proceedings of the Travel and Tourism Research Association Europe 2010. Annual Conference. 1-3 September, Budapest, Hungary (pp. 4555). Dalarna, Sweden: TTRA-Europe.

Hallem, Y., Barth, I., \& Triki, A. (2010). Customer perceived value of medical tourism: An exploratory study. The case of cosmetic surgery in Tunisia. In L. Puczkó (Ed.), Health, wellness and tourism: Healthy tourists, healthy business? Proceedings of the Travel and Tourism Research Association Europe 2010. Annual Conference. 1-3 September, Budapest, Hungary (pp. 56-65). Dalarna, Sweden: TTRA-Europe. 
Instituto Nacional de Engenharia, Tecnologia e Inovação-National Institute for Engineering, Technology \& Innovation (now renamed Laboratório Nacional de Energia e Geologia (LNEG) - National Laboratory for Energy \& Geology). (2004). Termalbase. Retrieved February 21, 2010, from http://e-geo.ineti.pt/ bds/termalbase/

Koh, S., Yoo, J.J.-E., \& Boger, C.A. (2010). Importance-performance analysis with benefit segmentation of spa goers. International fournal of Contemporary Hospitality Management, 22(5), 718-735.

Konu, H., \& Laukkanen, T. (2010). Predicting factors of tourists' interest towards wellbeing tourism holidays: A Finnish case. In L. Puczkó (Ed.), Health, wellness and tourism: Healthy tourists, healthy business? Proceedings of the Travel and Tourism Research Association Europe 2010. Annual Conference. 1-3 September, Budapest, Hungary (pp. 154-163). Dalarna, Sweden: TTRA-Europe.

Lapa, V.N.P.M.J. (2009). Águas, elites e desenvolvimento. A exploração das águas minerais naturais do concelho de Chaves pela Câmara Municipal (1892-1948). Unpublished doctoral dissertation, University of Trásos-Montes e Alto Douro (UTAD), Vila Real, Portugal.

Law, R., Qi, S., \& Buhalis, D. (2010). Progress in tourism management: A review of website evaluation in tourism research. Tourism Management, 31(3), 297-313.

Lazzeretti, L., \& Petrillo, C.S. (Eds.). (2006). Tourism local systems and networking. Oxford: Elsevier Science \& Technology.

Lehto, X.Y., Brown, S., Chen, Y., \& Morrison, A.M. (2006). Yoga tourism as a niche within the wellness tourism market. Tourism Recreation Research, 31(1), 5-14.

Medeiros, C.L., \& Cavaco, C. (Eds.) (2008). Turismo de saúde e bem-estar. Termas, spas termais e talassoterapia. Lisbon: CEPCEP-Universidade Católica Portuguesa.

Milheiro, E. (2006). A informação turística e as tecnologias da informação e da comunicação: $O$ caso português. Lisbon: Instituto de Turismo de Portugal.

Mourão, L.P. (2010, January 31). Spa E Thalasso Monitor. Presentation made at the opening conference of the Bolsa de Turismo de Lisboa (Lisbon Tourism Fair). Lisbon, Portugal: Turismo de Portugal.

Miniwatts Marketing Group. (2010). Internet usage in Europe. Internet user statistics $\mathcal{E}$ population for 53 European countries and regions. Retrieved September 17, 2010, from http://www.internetworldstats.com/ stats4.htm\#europe
NCAM (National Center for Accessible Media). (2010). Web access symbol. Retrieved March 8, 2010, from http://ncam.wgbh.org/ webaccess/symbolwinner.html

Pesonen, J., \& Palo-oja, O.-M. (2010, February 10-12). Comparing Internet commerce adoption between the Finnish and the European independent accommodation companies. Paper presented at the Enter 2010 conference 'Information and Communication Technologies in Tourism'. Lugano, Switzerland.

Smith, M., \& Laszlo, P. (2008). Health and wellness tourism.Oxford: Butterworth-Heineman.

Sousa, A. (2006). Termalismo em Portugal tem vindo a aumentar. Retrieved January 28, 2010, from http://www.aguaonline.co.pt/arquivo/noticias/ termalismo.htm

SpaFinder. (2010). Seventh Annual Forecast: 'Top 10 Global Spa Trends to Watch in 2010'. Press Release retrieved February 10, 2010, from http://www.spafinder.com/ about/press_release.jsp?relId $=185$

Swarbrooke, J., Smith, M., \& Onderwater, L. (Eds.). (2004). ATLAS reflections 2004: Networking and partnership in destinations and development management. Arnhem: ATLAS.

Taipas Turitermas. (2010). Taipas Turitermas. Plano de Actividades 2010/2013. Retrieved January 10, 2010, from http://www.taipasturitermas. pt/planodeactividades20102013.pdf

Turismo de Portugal. (2009a). Portugal e talassoterapia. Retrieved February 5, 2009, from http://www.visitportugal.com/NR/exeres/1F655FEDC76F-451D-9128-EE912C729B26, frameless.htm

Turismo de Portugal. (2009b). Termas em Portugal. A oferta e a procura em 2008. Lisbon, Portugal: Author.

Turismo de Portugal. (2010a). Luis Mourão. Retrieved January 13, 2010, from http://turismodeportugal.pt/conferenciasaudeebemestar/ default.aspx?content $=261$

Turismo de Portugal. (2010b). Saúde E bemestar. Qualificação da oferta de saúde e bem-estar. Projectos financiados pelo Turismo de Portugal. Lisbon, Portugal: Author. 